\title{
Cytotoxicity of Chitosan Oligomers Produced by Crude Enzyme Extract from the Fungus Metarhizium Anisopliae in Hepg2 and Hela Cells
}

Cristiane Fernandes de Assis ${ }^{1}$, Raniere Fagundes Melo-Silveira ${ }^{2}$, Ruth Medeiros de Oliveira ${ }^{2}$, Leandro Silva Costa ${ }^{2}$, Hugo Alexandre de Oliveira Rocha ${ }^{2}$, Gorete Ribeiro de Macedo ${ }^{1 *}$ and Everaldo Silvino dos Santos ${ }^{1}$

${ }^{1}$ Department of Chemical Engineering, Federal University of Rio Grande do Norte, Natal, Rio Grande do Norte, Brazil ${ }^{2}$ Department of Biochemistry, Federal University of Rio Grande do Norte, Natal, Rio Grande do Norte, Brazil

\begin{abstract}
Chitooligosaccharides exhibit biological activities, including antitumor, antimicrobial and antioxidant. In this study we used a mixture of chitooligosaccharides produced by enzymatic hydrolysis in two tumor cell lines and assessed the cell proliferation and cytotoxicity of these compounds. The proliferation of HeLa cells was inhibited around by $60 \%$.
\end{abstract}

Keywords: Chitooligosaccharides; HepG2 cells; HeLa cells; Cytotoxicity

\section{Introduction}

In recent years, the research for more efficient alternatives in the treatment of infectious and neoplastic diseases has mobilized professionals from a host of different areas. Promising results have emerged from the use of substances produced by microorganisms. Chitosanolytic enzymes from different microorganisms, including fungi [1] and bacteria [2], have been reported and used with excellent results in the production of chitooligosaccharides (COS)[3]. Chitooligosaccharides are partially hydrolyzed products of chitosan, within which pentamers and hexamers can be obtained as intermediate reactions [4]

Two methods can be used to obtain chitooligosaccharides: chemical and enzymatic. Chemical hydrolysis is carried out using high temperatures under acidic conditions and produces a large amount of glucosamine (chitosan monomer), compromising control over the reaction progress. This method produces low pentamer and hexamer yields. Enzymatic hydrolysis has a number of advantages for the production of chitooligosaccharides and some chitosanases may catalyze hydrolysis under mild conditions and not produce monosaccharides [4].

COS is applied more widely than chitosan in health-care, food,medicine, pesticides and feedstuffs. The anti-tumor activity of COS has been known since 1986 [5], and several mechanisms have been proposed. These include the regulation of immunity [6], the direct killing of tumor cells, or causing tumor cell apoptosis and inhibiting tumor angiogenesis [7].

The aim of this study was to quantify and analyze the chitooligosaccharides produced during 20 minutes of enzymatic hydrolysis of chitosan produced by fungus Metarhizium anisopliae and evaluates cell viability of these compounds in hepatocarcinome (HepG2) and uterine carcinome (HeLa) cells. The 3T3 cell lines, which are fibroblast cells, were used as standard non-toxic concentrations.

\section{Materials and Methods}

\section{Fermentation conditions}

The fungus Metarhizium anisopliae was kindly gifted by Embrapa Recursos Genéticos e Biotecnologia (Brasília/DF-Brazil). Ten milliliters of spore suspension $\left(10^{7}\right.$ spores $\left./ \mathrm{mL}\right)$ from a 5 -day culture in PDA medium were transferred using $2 \mathrm{~mL}$ of sterile water. Next, this spore suspension was once again transferred to a $250 \mathrm{~mL}$ Erlenmeyer containing $90 \mathrm{~mL}$ of culture medium consisting of: $0.2 \%$ chitosan, $0.1 \%$
$\mathrm{K}_{2} \mathrm{HPO}_{4}, 0.05 \% \mathrm{MgSO}_{4}, 0.5 \% \mathrm{KCl}, 0.3 \%$ yeast extract, $0.5 \%$ peptone, $0.2 \% \mathrm{NaNO}_{3}, 0.001 \% \mathrm{FeSO}_{4}(\mathrm{pH} 5.5)$; growth took place in a rotating incubator $(110 \mathrm{rpm})$ for 2 days at $25^{\circ} \mathrm{C}$. From this suspension, $10 \mathrm{~mL}$ was transferred to $90 \mathrm{~mL}$ of the same medium. After 48 hours of culture the broth was centrifuged at $13400 \times g$ for 15 minutes and the supernatant was used to determine the enzymatic activity assay.

\section{Enzyme activity}

Enzymatic activity was assessed by determining the reducing sugars generated by chitosan hydrolysis. In this case, $500 \mathrm{lL}$ of the fermented broth was mixed with $500 \mathrm{lL}$ of chitosan solution solubilized in hydrochloric acid $(0.1 \mathrm{~N})$. The reaction was carried out for $30 \mathrm{~min}$ at $55^{\circ} \mathrm{C}$. To terminate the reaction, $2.5 \mathrm{~mL}$ of dinitrosalicylic acid was added and then cooled in an ice bath, and quantification of the reducing sugars was performed using a spectrophotometer (Thermo Spectronic) at 600 $\mathrm{nm}[8]$ and a standard curve with D-glucosamine. One unit (U) of chitosanase was defined as the amount of enzyme that is capable of releasing $1 \mathrm{lmol}$ of reduced sugar equivalent to chitosan D-glucosamine/min.

\section{Chitooligosaccharide production}

The hydrolysis reaction of chitosan to obtain the chitooligosaccharides consisted of mixing a solution of $1 \%(\mathrm{~m} / \mathrm{v})$ soluble chitosan in chloridric acid ( $\mathrm{pH}$ adjusted with $\mathrm{NaOH}$ to 5.5) to the broth fermented at a ratio of $1: 1$; the mixture was maintained at $55^{\circ} \mathrm{C}$ for 20 minutes. The reaction was finalized by the thermal inactivation of the enzyme at $100^{\circ} \mathrm{C}$ for 10 minutes, followed by centrifugation at $13400 \mathrm{x} g$ for 15 minutes and filtration in a $0.22 \mu \mathrm{m}$ filtering membrane. Detection of glucosamine and of chitosan oligosaccharides from dimer to hexamer was determined by high-performance liquid chromatography using a CLC-NH $\mathrm{N}_{2}$ Shim-Pack column (Shimadzu Co, Japan). Oligomer analy-

*Corresponding author: Gorete Ribeiro de Macedo, Departamento de Engenharia Química ,Centro de Tecnologia, Av. Senador Salgado Filho, s/n, Lagoa Nova 50072-970 ,NATAL - Rio Grande do Norte, Brazil, Tel: 55-84-3215-3769; Fax: 5584-3215-3770; E-mail: cristianeassis@ufrnet.br

Received October 17, 2011; Accepted February 10, 2012; Published February 13,2012

Citation: de Assis CF, Melo-Silveira RF, de Oliveira RM, Costa LS, de Oliveira Rocha HA, et al. (2012) Cytotoxicity of Chitosan Oligomers Produced by Crude Enzyme Extract from the Fungus Metarhizium Anisopliae in Hepg2 and Hela Cells. J Bioprocess Biotechniq 2:114 doi: 10.4172/2155-9821.1000114

Copyright: () 2012 de Assis CF, et al. This is an open-access article distributed under the terms of the Creative Commons Attribution License, which permits unrestricted use, distribution, and reproduction in any medium, provided the original author and source are credited. 
sis was performed in HPLC with $60 \%$ acetonitrile as mobile phase and flow rate of $0.8 \mathrm{~mL} / \mathrm{min}$ and using an RI detector. The peaks of $(\mathrm{GlcN})_{\mathrm{n}=1-6}$ were identified and estimated using a standard calibration curve (1-10 $\mathrm{mg} / \mathrm{mL}$ ) according to Liang's equation [9].

\section{Cell culture}

Embryo 3 T3 fibroblast cells (ATCC CCL-164), HepG2 hepatocarcinome cells (ATCC HB-8065) and cervical adenocarcinome HeLa cells (ATCC CCL-2) were used for viability and cytotoxicity. The cells grew in DMEM medium (Dulbecco's Modified Eagle Medium) supplemented with $10 \%$ newborn calf serum (CUTILAB, CampinasSP, Brazil) and penicillin/streptomycin $(1 \mu \mathrm{g} / \mathrm{mL})$ (Sigma-Aldrich, St. Louis, USA). The cells were incubated in oven at $37^{\circ} \mathrm{C}$ under moisture atmosphere containing $5 \% \mathrm{CO}_{2}$. The viability assays were conducted in vitro as follows: $100 \mu \mathrm{L}\left(5 \times 10^{3}\right.$ cells) of cell suspension was plated in 96 well polystyrene plates. Cell adhesion was conducted for $12 \mathrm{~h}$. Before the addition of chitosan oligomers, the medium with the non-adhered cells was removed and the medium containing the oligomers (from 0.1 to $1 \mathrm{mg} / \mathrm{mL}$ ) was used. A control without oligomers was also used. After treatment, the cytotoxic effect of the chitosan oligomers in HepG2, HeLa 3T3 cells was determined using the MIT method described by Mosmann [10] with some modifications. The cells were washed with PBS at $37^{\circ} \mathrm{C}$ and then $100 \mu \mathrm{L}$ of serum-free medium containing $0.5 \mathrm{mg} /$ $\mathrm{mL}$ of MTT was added to each well. After 4 hours of incubation, the culture medium was removed and $100 \mu \mathrm{L}$ of isopropyl alcohol was added to each well for solubilization of the formazan formed. The plates were agitated for 10 minutes and the mean absorbance of the plate was measured in the spectrophotometer at $570 \mathrm{~nm}$ [11]. The absorbance of the treated cells was compared with that of the control. The control cells were considered $100 \%$ viable, whereas the percentage of cell growth inhibition was calculated for those treated with the hydrolysate. All the analyses were conducted in triplicate.

\section{Statistic analysis}

All data were expressed as mean \pm standard deviation. Statistical analysis was done by one-way Anova using the SIGMAStat version 2.01 computer software. Student-Newmans-Keuls post-tests were performed for multiple group comparison. In all cases statistical significance was set at $\mathrm{p}<0.05$.

\section{Results and Discussion}

The products of chitosan hydrolysis were analyzed by HPLC. Figure 1 shows the chromatogram obtained for a hydrolysis time of 20 minutes using the crude enzyme extract. This figure also demonstrates the formation of monomers $(\mathrm{GlcN})$, trimers $(\mathrm{GlcN})_{3}$, tetramers $(\mathrm{GlcN})_{4}$ and pentamers $(\mathrm{GlcN})_{5}$ at concentrations of $6.532 ; 0.792 ; 0.395$ and $0.352(\mathrm{mg} / \mathrm{mL})$, respectively. The monomer (glucosamine) shows the highest concentration. Such a polymer profile suggests the presence of enzymes with exo and endochitosanase activity $[12,13]$.

Figure 2 shows the cytotoxicity of the tested compounds in tumor and normal cells. In the MTT assays we used different hydrolysate concentrations containing a mixture of chitooligosaccharides $(0.1-1 \mathrm{mg} /$ $\mathrm{mL}$ ) in the different cell lines.

The cells were treated with different concentrations of the supernatant, for 72 hours. In the absence of these compounds the reduction of MTT was considered as being $100 \%$. The experiment was carried out in 96-well plates. The results represent the mean \pm SD of three experiments in triplicate $(\mathrm{p}<0.05)$.

The $3 \mathrm{~T} 3$ cells were used as control to assess the toxicity of the com-

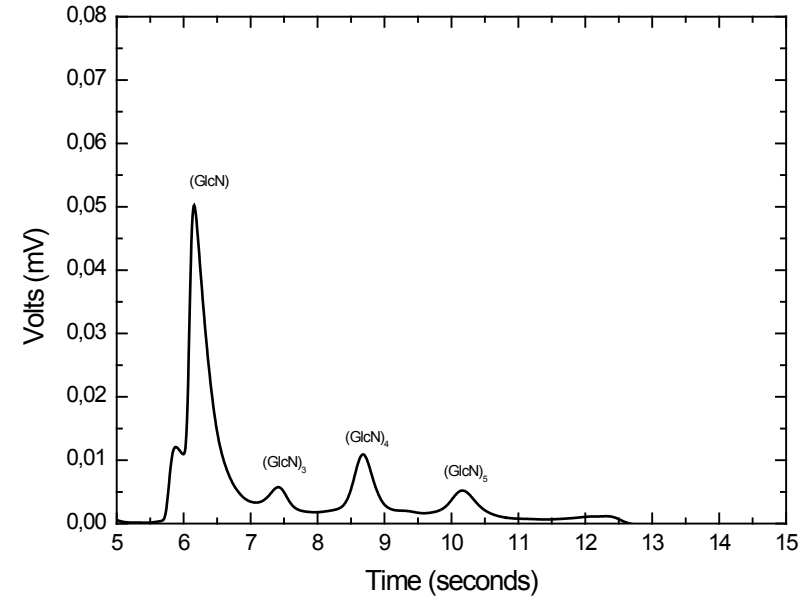

Figure 1: Chromatograms of hydrolyzed chitosan formed by the incubation of chitosan with the crude enzyme extract during 20 minutes.

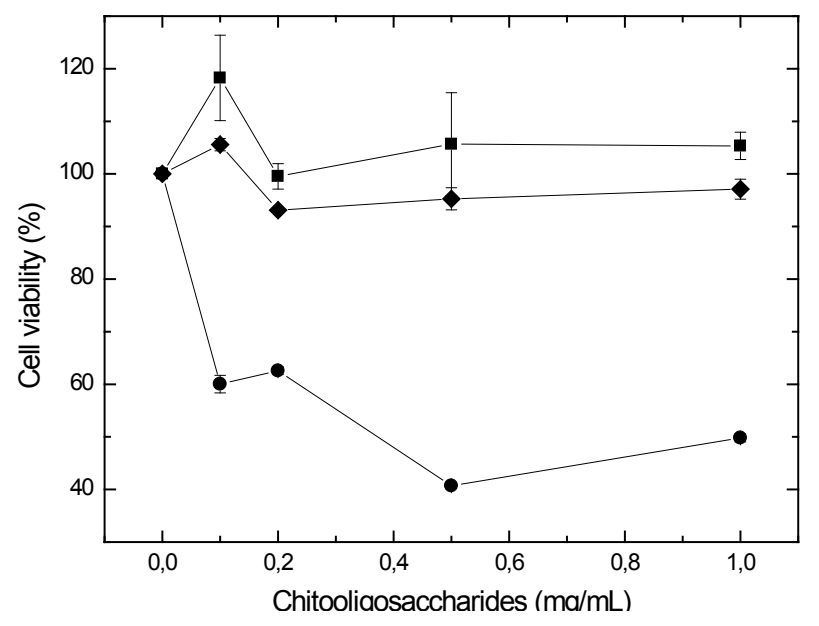

Figure 2: Cytotoxic assessment of the effect of the olygomer mixture in HepG2 (घ), HeLa $(\bullet)$ and 3T3 $(\bullet)$ cells.

pound. When these cells were treated with the hydrolysate containing the chitosan oligomers, no alteration in cell proliferation was detected. Thus, the tumor cells (HepG2 and HeLa) were treated with concentrations that were non-toxic to normal cells.

The HepG2 cells, when treated with the chitooligosaccharides at a concentration of $0.2 \mathrm{mg} / \mathrm{mL}$, induced cell viability of around $20 \%$ and at higher concentrations, it remained practically unaltered. These results corroborate literature data, in that chitooligosaccharides did not show any activity against Hep3B cells [14,15].

In the HeLa cells, diminished cell viability was directly proportional to the increase in concentration, where cell viability decreased by $60 \%$ at a concentration of $0.5 \mathrm{mg} / \mathrm{mL}$. Similar results were found by Jeon and Kim [16], where chitooligosaccharides inhibited uterine tumors in rats by $73.6 \%$. The modified chitooligosaccharides used in HeLa cells showed an $\mathrm{IC}_{50}$ value of $0.45 \mathrm{mg} / \mathrm{mL}$ [14] and similar results were found in this study, where IC50 was $0.67 \mathrm{mg} / \mathrm{mL}$. Kim and Rajapakse [12] observed that a mixture of chitosan oligomers from tetramer to pentamer could inhibit tumor cell growth in rats. It was observed 
Citation: de Assis CF, Melo-Silveira RF, de Oliveira RM, Costa LS, de Oliveira Rocha HA, et al. (2012) Cytotoxicity of Chitosan Oligomers Produced by Crude Enzyme Extract from the Fungus Metarhizium Anisopliae in Hepg2 and Hela Cells. J Bioprocess Biotechniq 2:114 doi: $10.4172 / 2155-$ 9821.1000114

that HeLa cells were more sensitive then the other ones showing that the biological functions of chitooligosaccharides depend not only on the degree of polymerization, but also on its molecular weight [12-16].

\section{Conclusion}

According to the results obtained, chitooligosaccharides may reduce the viability of HeLa tumor cells. The effect of the antitumor activity of chitooligosaccharides is mainly due to stimulation in the immune system, increasing in vivo macrophage activity. However, according to our findings, chitosan oligomers act directly on HeLa tumor cells, decreasing cell proliferation and viability. Moreover, it is interesting to observe the non-toxicity of the compound in $3 \mathrm{~T} 3$ fibroblast cells.

\section{Acknowledgements}

The authors thank Financiadora de Estudos e Projetos (FINEP), Conselho Nacional de Desenvolvimentos Científico e Tecnológico (CNPq) and (Coordenação de Aperfeiçoamento de Pessoal de Nível Superior (CAPES) for financial support that made this work possible.

\section{References}

1. Kim SY, Shon DH, Lee KH (1998) Purification and characteristics of two types of chitosanases from Aspergillus fumigatus KH-94. J Microbiol Biotechol 8: 568 -574 .

2. Lee HW, Choi JW, Han DP, Lee NW, Park SL, et al. (1996) Identification and production of constitutive chitosanase from Bacillus sp. HW-002. J Microbiol Biotech 6: 12-18.

3. Zhang H, Du Y, Yu X, Mitsutomi M, Aiba SI (1999) Preparation of chitooligosaccharides from chitosan by a complex enzyme. Carbohydr Res 320: 257-260.

4. Ming M, Kuroiwa T, Ichikawa S, Sato S, Mukataka S (2006) Production of chitosan oligosaccharides by chitosanase directly immobilized on an agar gelcoated multidisk impeller. Biochem Engin J 28: 289-294.

5. Suzuki K, Mikami T, Okawa Y, Tokoro A, Suzuki S, et al. (1986) Antitumor effect of hexa-N-acetylchitohexaose and chitohexaose Carbohydr Res 151: 403-408.
6. Yu Z, Zhao L, Ke H (2004) Potential role of nuclear factor-kappaB in the induction of nitric oxide nd tumor necrosis factor-alpha by oligochitosan in macrophages. Int Immunopharmacol 4: 193-200.

7. Prashanth KVH, Tharanathan RN (2005) Depolymerized products of chitosan as potent inhibitors of tumor-induced angiogenesis. Biochimica et Biophysica Acta 1722: 22-29.

8. Miller GL (1959) Use of Dinitrosalicylic Acid Reagent for Determination of Reducing Sugar. Anal Chem 31: 426-428.

9. Liang TW, Chen YJ, Yen YH, Wang SL (2007) The antitumor activity of the hydrolysates of chitinous materials hydrolyzed by crude enzyme from Bacillus amyloliquefaciens V656. Proc Biochem 42: 527-534.

10. Mosmann T (1983) Rapid colorimetric assay for cellular growth and survival Application to proliferation and cytotoxicity assays. J Immunol Methods 65: 5563.

11. Denizot F, Lang R (1986) Rapid colorimetric assay for cell growth and survival: Modifications to the tetrazolium dye procedure giving improved sensitivity and reliability. J Immunol Methods 89: 271-277

12. Kim SK, Rajapakse N (2005) Enzymatic production and biological activities of chitosan oligosaccharides (COS): A review. Carbohydr Pol 62: 357-368.

13. Assis CF, Araújo NK, Pagnoncelli MGB, Pedrini MRS, Macedo GR, et al. (2010) Chitooligosaccharides enzymatic production by Metarhizium anisopliae. Bioprocess Biosys Eng 33: 893-899.

14. Assis CF, Costa LS, Melo-Silveira RF, Oliveira RM, Pagnoncelli MGB, et al (2011) Chitooligosaccharides antagonize the cytotoxic effect of glucosamine World J Microbiol Biotechnol 28: 1097-1105.

15. Jeon YJ, Kim SK (2002) Antitumor Activity of Chitosan Oligosaccharides Produced in Ultrafiltration Membrane Reactor System. J Microbiol Biotechnol 12 503-507.

16. Shen KT, Chen MH, Chan HY, Jeng JH, Wang YJ (2009) Inhibitory effects of chitooligosaccharides on tumor growth and metastasis. Food Chem Toxic 47 1864-1871. 